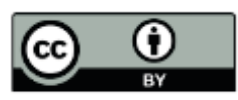

\title{
Evaluating Colombian public hospitals productivity during 2004-2015. A Luenberger-Indicator approach*
}

Evaluación de la productividad en hospitales públicos colombianos
entre 2004-2015. Una aproximación desde el indicador Luenberger

Avaliação da produtividade em hospitais públicos colombianos entre 2004-2015. Uma aproximação desde o indicador Luenberger

Received: September 10, 2019. Accepted: November 30, 2019. Published: October 1, 2020.

DOI: https://doi.org/10.11144/Javeriana.rgps19.ecph

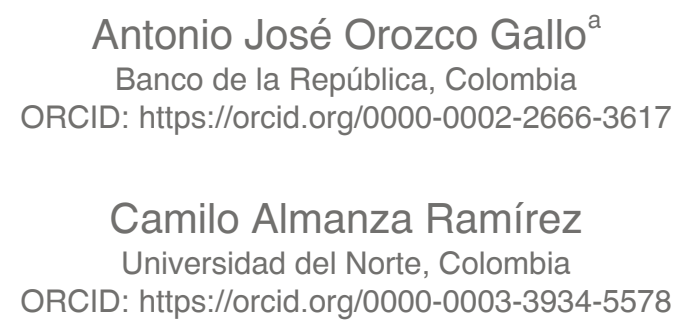

Cited as Orozco A, Almanza C. Evaluating Colombian public hospitals productivity during 2004-2015. A Luenberger-Indicator approach. Rev Gerenc Polit Salud. 2020;19. https://doi.org/10.11144/Javeriana.rgps19.ecph

\footnotetext{
${ }^{\mathrm{a}}$ Corresponding author. E-mail: ajosegallo@gmail.com
} 


\section{Abstract}

Background: In Colombia, public policy has encouraged hospital efficiency and sustainability since 1993, when its health system underwent a profound change with the Law 100. Method: We estimate the efficiency and productivity of Colombian public hospitals using the Luenberger productivity indicator. This less restrictive indicator allows for a disaggregated regional analysis and does not overestimate the change in productivity when compared to other measures. It was made an empirical application to a sample of 260 hospitals during the 2004-2015 period. Results: The results show a productivity decline for Colombian public hospitals, explained mainly by the decrease in technological change as a result of low investment in technology. In fact, one out of every eighty-seven hospitals reached an improvement in efficiency and technological change simultaneously, while, one out of every two experienced the opposite. On average, hospitals in all regions showed a productivity decrease, in particular those in the Eastern region, an area that accounted, with the Central region, three-fifths of the overall decline. Discussion and conclusion: The efficiency and productivity that was sought to be achieved through the profound change in the health system were insufficient. Thus, governmental measures should: encourage managers to modernize their administrative and organizational factors, promote the development of technology and research in health by greater investments, and foster complementary and non-competitive relationships among hospitals.

Keywords: Health economics, Health care policy, Public hospitals, Luenberger productivity indicator.

\section{Resumen}

Antecedentes: en Colombia, las políticas públicas han promovido la eficiencia y sostenibilidad hospitalaria desde 1993, cuando, a partir de la Ley 100, el sistema de salud afrontó un profundo cambio. Método: se estimaron la eficiencia y productividad de los hospitales públicos en Colombia utilizando el indicador de productividad Luenberger. En comparación con otras medidas, este indicador es menos restrictivo al permitir análisis regionales desagregados y no hacer sobreestimaciones de la productividad. Se realizó una aplicación empírica en una muestra de 260 hospitales en el periodo 2004-2015. Resultados: los resultados muestran una disminución de la productividad en los hospitales públicos colombianos, debida especialmente a la reducción del cambio tecnológico como resultado de la baja inversión en tecnología. De hecho, uno de cada 87 hospitales alcanzó mejorías en los cambios relativos a eficiencia y tecnología simultáneamente, mientras que uno de cada dos experimentó lo contrario. En promedio, los hospitales de todas las regiones mostraron una reducción de la productividad, en particular, los de la región oriental, un área que contabiliza, junto con la región central, tres quintas partes de la reducción total. Discusión y conclusión: la eficiencia y productividad que debieron ser alcanzadas a través de los profundos cambios en el sistema de salud fueron insuficientes. Por lo tanto, las medidas gubernamentales deben: incentivar a los directivos a modernizar sus factores administrativos y organizacionales, promover el desarrollo de tecnología e investigación en salud por parte de grandes inversores, y estimular las relaciones complementarias y no competitivas entre hospitales.

Palabras clave: Economía de la salud, política de asistencia sanitaria, hospitales públicos, indicador de productividad Luenberger.

\section{Resumo}

Antecedentes: em Colômbia, as políticas públicas têm promovido a eficiência e sustentabilidade hospitalar desde 1993, quando, a partir da Lei 100, o sistema de saúde encarou uma mudança profunda. Método: foram estimadas a eficiência e produtividade dos hospitais públicos em Colômbia utilizando o indicador de produtividade Luenberger. Em comparação com outras medidas, este indicador é menos restritivo ao permitir análises regionais desagregados e não fazer superestimações da produtividade. Foi realizada uma aplicação empírica em uma amostra de 260 hospitais durante o período 2004-2015. Resultados: os resultados mostram uma diminuição da produtividade nos hospitais públicos colombianos, devida especialmente à redução da mudança tecnológica como resultado do baixo investimento em tecnologia. De fato, um de cada 87 hospitais alcançou melhorias nas mudanças relativas à eficiência e tecnologia simultaneamente, enquanto um de cada dois experimentou o contrário. Em média, os hospitais de todas as regiões mostraram uma redução da produtividade, em particular, os da região oriental, uma área que contabiliza, junto com a região central, três quintas partes da redução total. Discussão e conclusão: A eficiência e produtividade que devessem ser atingidas a traves das profundas mudanças no sistema de saúde foram insuficientes. Por tanto, as medidas governamentais devem: incentivar aos diretivos a modernizar seus fatores administrativos e organizacionais, promover o desenvolvimento de tecnologia e pesquisa em saúde por parte de grandes investidores, e estimular as relações complementárias e não competitivas entre hospitais. 


\section{Introduction}

The performance of hospitals has been associated with the attainment of the health targets of countries, which is why governments devote their greatest efforts to improve efficiency and productivity of these organizations (1).

In Colombia, inefficiency in the provision of health services was one of the aspects that urged the structural reform of the social security system approved by the Law 100 of 1993, which established the current health system. Under this new regulatory framework, public hospitals had to transform into autonomous companies capable of competing in a market system ${ }^{1}$ (2). In other words, public hospitals would not receive resources directly from the public budget anymore, and consequently, had to become self-sustaining entities in order to guarantee their permanence in the system $(3,4)$.

Productivity measures can be classified into those that relate an output to an input (single factor productivity measure), and those that relate an output to a package of inputs (multifactor productivity measure). Similarly, there are different parametric and non-parametric techniques and procedures for performing such measurements.

In the empirical literature on hospital productivity, the use of the Malmquist Productivity Index, estimated by the non-parametric technique known as Data Envelopment Analysis (DEA) has enjoyed great popularity $(5,6)$. Non-parametric techniques have the advantage that they do not require specifying the functional form of production technology. In addition, it allows identifying the sources of inefficiency, and, consequently, how it can be overcome (7). The Luenberger indicator, introduced by Chambers et al. (8), has recently been used to measure productivity. This indicator uses the directional distance function - a generalization of the distance functions introduced by Shepard (9) - which allows expanding outputs and contracting inputs simultaneously, contrary to other measures of total factor productivity like the Malmquist Index, which assume that one of the components remains constant (10).

The objective of this study is to evaluate the efficiency and productivity of public hospitals in Colombia for the 2004-2015 period from a sample of 260 hospitals using the Luenberger productivity indicator (LPI). This indicator, when compared to other measures, is less restrictive, allows for a disaggregated analysis, and does not overestimate the productivity change.

This article is structured as follow. The first section presents, among this introduction, the Colombian health system and reviews the literature. The second, details the applied methodology, and defines the source of the data, the variables selected and the homogeneous groups of hospitals design. The third, presents the results of hospitals' productivity and efficiency analysis. Finally, in the fourth section conclusion and discussion are presented.

The Colombian health care system, regulated by the Law 100 of 1993 and called General System of Social Security in Health (Sistema General de Seguridad Social en Salud, SGSSS), sought to 
achieve universal coverage, increase efficiency in the use of resources, and improve the quality of services (11). According to the current regulatory framework, the system works as follows: regulatory agencies, led by the Ministry of Health and Social Protection (Ministerio de Salud $y$ Protección Social, MSP), define a benefit plan for the population known as the Mandatory Health Plan (Plan Obligatorio de Salud, POS) ${ }^{2}$.

The Health Promoting Companies (Empresas Promotoras de Salud, EPS) are the institutions in charge of administration, and they must guarantee the POS to costumers through contracting with health service providers ${ }^{3}$, integrated mainly by public and private hospitals (see table 1). Costumers access to health care services under two assurance scenarios: the Contribution Regime (Régimen Contributivo, RC) and the Subsidized Regime (Régimen Subsidiado, RS). The first one covers the population with capacity to pay (paying costumers), and the second one covers the poor and vulnerable population that cannot afford it (beneficiary) ${ }^{4}$.

Table 1 Members of SGSSS

\begin{tabular}{|c|l|l|}
\hline 1 & Regulation & $\begin{array}{l}\text { - Ministry of Health and Social Protection and } \\
\text { its associated health entities* }\end{array}$ \\
\hline 2 & Administration & - Health Promoting Companies \\
\hline 3 & Healthcare providers & $\begin{array}{l}\text { - Public hospitals } \\
\text { Private hospitals } \\
\text { - Independent professionals }\end{array}$ \\
\hline 4 & Customers & $\begin{array}{l}\text { - Paying customers } \\
\text { Beneficiaries }\end{array}$ \\
\hline
\end{tabular}

* Associated health entities that perform management, surveillance and control functions.

Source: Own elaboration based on the Law 100 of 1993 and its reforms.

SGSSS changed the way public hospitals were financed and operated. Prior to Law 100, hospitals obtained their resources through national transfers. In contrast, the change in the current system forced them to manage their own resources in a model of regulated competition between public and private institutions. Thus, public hospital resources come mainly, as follows: sales revenue from healthcare services, contributions in cash and in-kind from national and regional entities, and other contributions for specific destination ${ }^{5}$. In this way, hospitals were forced to optimize their resources in order to facilitate their permanence in the system (3). After all, deficiencies in the implementation of this reform related to the non-equalization of conditions for public hospitals to compete adequately with other agents (3), generated a crisis in the national public hospital network $(12,4)$. Hence, these institutions fall into a financial imbalance associated, among other factors, with the low operative and administrative efficiency to manage their own income $(12,2)$. 
Since the seminal work of Tinbergen (13), the economic theory of productivity measurement has developed considerably, following the major contributions by Dale Jorgenson, Zvi Griliches and Erwin Diewert. Now, the theoretical approach to productivity measurement offers a consistent and well-founded approach that integrates the theory of the firm, index number theory, and national accounts.

Recent literature in the field of health economics has focused on measuring hospital efficiency and productivity over time. A number of non-parametric and parametric methods have been applied to evaluate the production frontier shifting, for the sake of determine productivity change. According to this survey of the literature, the majority of researches have applied Data Envelopment Analysis (DEA), as a non-parametric method, to derive productivity measures by Malmquist index application ${ }^{6}$ (see table 2).

Table 2 Some selected studies on the productivity of hospitals (Cont.)Cont.)

\begin{tabular}{|c|c|c|c|c|}
\hline \multicolumn{2}{|r|}{ Author } & Method & Approach & Sample \\
\hline (5) & $\begin{array}{l}\text { Barros et al. } \\
(2008)\end{array}$ & DEA & LPI, MPI & $\begin{array}{l}\text { 51 hospitals; national; Portugal; } \\
\text { 1997-2004 }\end{array}$ \\
\hline (14) & $\begin{array}{l}\text { Kittelsen et al. } \\
(2015)\end{array}$ & $\begin{array}{l}\text { Bootstrapped DEA; } \\
\text { SFA }\end{array}$ & MPI & $\begin{array}{l}316 \text { hospitals; university, capital } \\
\text { city; Finland, Sweden, Denmark, } \\
\text { Norway; 2005-2007 }\end{array}$ \\
\hline (15) & $\begin{array}{l}\text { Nghiem et al. } \\
\text { (2011) }\end{array}$ & DEA / SFA & MPI & $\begin{array}{l}35 \text { hospitals; public; Australia, } \\
\text { 1996-2004 }\end{array}$ \\
\hline (16) & Linna (1998) & DEA/SFA & MPI & $\begin{array}{l}43 \text { hospitals; acute care; Finland; } \\
\text { 1988-1994 }\end{array}$ \\
\hline (17) & $\begin{array}{l}\text { Gabbitas \& Jeffs } \\
(2008)\end{array}$ & SFA & $\begin{array}{l}\text { Random and } \\
\text { fixed effects } \\
\text { models }\end{array}$ & $\begin{array}{l}8 \text { public acute care hospital systems; } \\
\text { state, territory; Australia; } 1996-97 \text { to } \\
2005-2006\end{array}$ \\
\hline (18) & $\begin{array}{l}\text { Granderson \& } \\
\text { Tauchen (2016) }\end{array}$ & $\begin{array}{l}\text { Approximation to a } \\
\text { divisia index }\end{array}$ & $\begin{array}{l}\text { TDI and a } \\
\text { stochastic cost } \\
\text { frontier }\end{array}$ & $\begin{array}{l}248 \text { hospitals; private nonprofit, } \\
\text { public; U.S.; 1996-1999 }\end{array}$ \\
\hline (19) & $\begin{array}{l}\text { Chowdhury et al. } \\
\text { (2014) }\end{array}$ & DEA & $\begin{array}{l}\text { MPI and non- } \\
\text { parametric } \\
\text { density } \\
\text { estimation }\end{array}$ & $\begin{array}{l}113 \text { acute care hospitals; } \\
\text { independent, private non-for-profit; } \\
\text { Ontario, Canada; 2002-2006 }\end{array}$ \\
\hline (20) & Wu et al. (2013) & $\begin{array}{l}\text { Non-radial DEA } \\
\text { approach based on } \\
\text { output-oriented } \\
\text { directional distance } \\
\text { function }\end{array}$ & RML & $\begin{array}{l}286 \text { hospitals; national; Taiwan; } \\
\text { 2002-2004 }\end{array}$ \\
\hline
\end{tabular}

Sources: Own elaboration. 
Table 2 Some selected studies on the productivity of hospitals (Cont.)

\begin{tabular}{|c|c|c|c|c|}
\hline \multicolumn{2}{|r|}{ Author } & Method & Approach & Sample \\
\hline (21) & $\begin{array}{l}\text { Burgess \& Wilson } \\
(1995)\end{array}$ & $\begin{array}{l}\text { DEA - Distance } \\
\text { function }\end{array}$ & MPI & $\begin{array}{l}1480 \text { hospitals; local government } \\
\text { entities, nonprofit organizations, for- } \\
\text { profit firms, veterans affairs; U.S.; } \\
1985-1988\end{array}$ \\
\hline (22) & $\begin{array}{l}\text { McCallion et al. } \\
(2000)\end{array}$ & DEA & MPI & $\begin{array}{l}23 \text { hospitals; Northern hospitals; } \\
\text { Ireland; 1986/89-1989/92 }\end{array}$ \\
\hline (23) & Färe et al. (1994) & DEA & MPI & $\begin{array}{l}17 \text { hospitals; public; Sweden; 1970- } \\
1985\end{array}$ \\
\hline (24) & $\begin{array}{l}\text { Kirigia et al. } \\
(2008)\end{array}$ & DEA & MPI & $\begin{array}{l}28 \text { public hospitals; municipal; } \\
\text { Angola; 2000-2002 }\end{array}$ \\
\hline$(25)$ & $\begin{array}{l}\text { Tlotlego et al. } \\
(2010)\end{array}$ & DEA & MPI & $\begin{array}{l}21 \text { non-teaching hospitals; district, } \\
\text { mission, primary; Republic of } \\
\text { Botswana; 2006-2008 }\end{array}$ \\
\hline (26) & $\begin{array}{l}\text { Gok \& Sezen } \\
(2012)\end{array}$ & DEA & MPI & $\begin{array}{l}226 \text { hospitals; teaching and non- } \\
\text { teaching; Turkey; 2001-2007 }\end{array}$ \\
\hline (27) & $\begin{array}{l}\text { De Castro et al. } \\
(2010)\end{array}$ & DEA & MPI & $\begin{array}{l}30 \text { general teaching hospitals; } \\
\text { Federal Brazilian Universities; } \\
\text { Brazil; 2003-2006 }\end{array}$ \\
\hline (28) & Wei (2006) & DEA & MPI & $\begin{array}{l}110 \text { hospitals; public, proprietary, } \\
\text { private; Taiwan; } 2000-2004\end{array}$ \\
\hline (29) & $\begin{array}{l}\text { Dimas et al. } \\
(2012)\end{array}$ & DEA & $\begin{array}{l}\text { MPI - } \\
\text { Censored tobit } \\
\text { model }\end{array}$ & $\begin{array}{l}22 \text { hospitals; public; Greece; } 2003- \\
2005\end{array}$ \\
\hline (30) & $\begin{array}{l}\text { Karagiannis \& } \\
\text { Velentzas (2012) }\end{array}$ & DEA & MPI & $\begin{array}{l}8 \text { hospitals; rural public; Greece; } \\
2002-2007\end{array}$ \\
\hline (31) & $\begin{array}{l}\text { Huerta et al. } \\
(2011)\end{array}$ & DEA & MPI & $\begin{array}{l}\text { 3.178 hospitals; national; U.S.; } \\
\text { 2002-2006 }\end{array}$ \\
\hline (32) & Li et al. (2014) & DEA & MPI & $\begin{array}{l}2 \text { hospitals; public third-grade Class } \\
\text { A; China; 2006-2009 }\end{array}$ \\
\hline (33) & $\begin{array}{l}\text { Mogha et al. } \\
(2015)\end{array}$ & DEA & MPI & $\begin{array}{l}27 \text { hospitals; government; India; } \\
2001-2011\end{array}$ \\
\hline (34) & Sulku (2012) & DEA & MPI & $\begin{array}{l}769 \text { hospitals; province; Turkey; } \\
\text { 2001-2006 }\end{array}$ \\
\hline (35) & NG (2011) & DEA & MPI & $\begin{array}{l}463 \text { hospitals; regional Guangdong } \\
\text { province; China; 2004-2008 }\end{array}$ \\
\hline (36) & $\begin{array}{l}\text { Ferrier \& } \\
\text { Valdmanis (2004) }\end{array}$ & DEA & MPI & $\begin{array}{l}76 \text { hospitals; non-profit; U.S.; 1996- } \\
1998\end{array}$ \\
\hline (37) & Roh et al. (201 la) & DEA & MPI & $\begin{array}{l}118 \text { hospitals; non-profit; U.S.; } \\
1999-2003\end{array}$ \\
\hline (38) & Roh et al. (2011b) & DEA & MPI & $\begin{array}{l}64 \text { hospitals; community, rural and } \\
\text { non-profits; Colorado U.S.; 1992- } \\
2003\end{array}$ \\
\hline (39) & Chu et al. (2011) & DEA & MPI & $\begin{array}{l}102 \text { teaching hospitals; private and } \\
\text { public; Taiwan; 1996-2001 }\end{array}$ \\
\hline (40) & Chen (2006) & DEA & MPI & $\begin{array}{l}40 \text { hospitals; medical centers, } \\
\text { regional public and private; Taiwan; } \\
\text { 1995-1998 }\end{array}$ \\
\hline
\end{tabular}

Sources: Own elaboration. 
Table 2 Some selected studies on the productivity of hospitals (Cont.)

\begin{tabular}{|c|c|c|c|c|}
\hline \multicolumn{2}{|r|}{ Author } & Method & Approach & Sample \\
\hline (41) & $\begin{array}{l}\text { Chang et al. } \\
(2011)\end{array}$ & DEA & MPI & $\begin{array}{l}31 \text { hospitals; regional (public and } \\
\text { private); Taiwan; 1998-2004 }\end{array}$ \\
\hline$(42)$ & $\begin{array}{l}\text { Arocena \& García- } \\
\text { Prado (2007) }\end{array}$ & $\begin{array}{l}\text { DEA - Output } \\
\text { distance function }\end{array}$ & $\begin{array}{l}\text { Hyperbolic } \\
\text { MPI }\end{array}$ & $\begin{array}{l}20 \text { public hospitals; reference, } \\
\text { specialized, regional and } \\
\text { rural; Costa Rica; 1997-2001 }\end{array}$ \\
\hline (43) & Pham (2011) & DEA & MPI & $\begin{array}{l}101 \text { public hospitals; central and } \\
\text { provincial; Vietnam; 1998-2006 }\end{array}$ \\
\hline (44) & $\begin{array}{l}\text { Sommersguter- } \\
\text { Reichmann (2000) }\end{array}$ & DEA & MPI & $\begin{array}{l}22 \text { hospitals; public, non-profit, } \\
\text { private; Austria; 1994-1998 }\end{array}$ \\
\hline$(45)$ & $\begin{array}{l}\text { Maniadakis } \\
\& \text { Thanassoulis } \\
(2000)\end{array}$ & DEA & MPI & $\begin{array}{l}75 \text { hospitals; national; Scotland; } \\
\text { 1991/2-1995/6 }\end{array}$ \\
\hline (46) & Zere et al. (2001) & DEA & MPI & $\begin{array}{l}86 \text { hospitals; Western Cape } \\
\text { province, South Africa; 1992/93- } \\
1997 / 98\end{array}$ \\
\hline (47) & $\begin{array}{l}\text { Sola \& Prior } \\
(2001)\end{array}$ & DEA & MPI & $\begin{array}{l}20 \text { hospitals; private and public; } \\
\text { Spain; 1990-1993 }\end{array}$ \\
\hline (48) & Gannon (2008) & DEA & MPI & $\begin{array}{l}60 \text { hospitals; regional (teaching); } \\
\text { Ireland; 1995-1998 }\end{array}$ \\
\hline (49) & $\begin{array}{l}\text { Nabilou et al. } \\
(2016)\end{array}$ & DEA & MPI & $\begin{array}{l}17 \text { hospitals; affiliated to Tehran } \\
\text { University of Medical Sciences; } \\
\text { Iran; } 2009-2014\end{array}$ \\
\hline
\end{tabular}

Sources: Own elaboration.

The assessment of hospital productivity change has encompassed different periods. Early studies focused on evaluating this institutions performance since the seventies to the early nineties (16,21-23). Nonetheless, the greatest part of empirical contributions has been concentrated on the noughties $(14,19,20,24-35)$. In the geographical context, literature has emphasized in both developed and developing countries. In the former, productivity analysis has been predominantly applied in U.S. institutions (18,21,31,36-38); meanwhile, in the latter, it has been focused on Taiwanese hospitals (20,28,39-41). Equally important, as a feature in common on literature, is the use of public hospital as a decision-making unit (DMU) $(15,17,23,24,29,30,32,42,43)$.

Even though most of the literature used human resources and beds to proxy labor and capital inputs, respectively; there are differences in how they measure them. In particular, labor is commonly measured in staff number; however, studies as $(19,27,36-38,43,44)$ express it in comparable units of time such as full-time equivalent, and studies as $(14,16,23,29,45,46)$ represent it in terms of cost. Within the same line, specification of outputs has relied mostly in outpatient visits and inpatient days. In this respect, some authors $(14,17-19,21,34,42,45)$ adjust the outputs for case-mix differences using weights. Others $(5,14,16,23,29,34,43,47)$ implement the length of stay as an additional output. Lastly, a number of researches $(30,34,40,41,47)$ complement their analysis introducing the quality of health care services. 
According to the results, empirical studies found that technological change was the main component in explaining hospital performance. In fact, most of the researches that found an increase in productivity ascribed this result to a technological progress $(5,15,16,22,28,32,34,35,37,38,44,48)$, While drop in productivity is ascribed to a technological regress $(21,23,25,27,40,46,47,49)$. It is worth noting that the quality of health care services explained productivity fell in (30), and productivity growth in (41).

\section{Methods}

To measure the efficiency and productivity of hospitals, parametric and non-parametric frontier techniques have been used. Parametric methods require a functional specification that presupposes the form of the frontier - generally, flexible forms such as Cobb-Douglas, trans-logarithmic, or Fourier are adopted. Parametric frontier techniques include the Stochastic Frontier Approach (SFA), the Distributions Free Approach (DFA) and the Thick Frontier Approach (TFA). These measurement techniques differ fundamentally in the form imposed on the frontier and in the assumptions that are made, regarding the density function of the error term and inefficiency. Non-parametric techniques such as the DEA and the Free Disposal Hull $(\mathrm{FDH})$, do not require the specification of any functional form of the production function and allow easy modeling of multiproduct technologies ${ }^{7}$.

In the empirical literature on hospital productivity, the use of the Malmquist Productivity Index calculated using DEA has been popular among researchers. Recently, the LPI has acquired importance for this type of analysis, which is why there are few studies that use this approach.

This study used DEA to estimate the directional distance functions that permit calculating and decomposing the LPI for Colombian hospitals during the 2004-2015 period. The directional distance function allows for simultaneous calculation of the maximum contraction of input and increase of output in a predetermined direction, in order to reach the efficient production frontier. The distance function enables assessing the economic scale that can be achieved, and possible improvements in production. In addition, it provides a benchmark when defining a reference point to be reached (5).

For the sake to apply the methodology, consider that the hospital productive process uses $x=\left(x_{1}, \ldots, x_{N}\right) \in R_{+}^{N}$ inputs (i.e personnel, infrastructure, equipment, and financial resources) to produce $y=\left(y_{1}, \ldots, y_{M}\right) \in R_{+}^{M}$ outputs $(50,51)$. A hospital's physical technology is the set of inputs that can produce outputs. We represent this technology by,

$$
T=\left\{(x, y) \in R_{+}^{N+M}: x \text { can produce } y\right\}
$$


It is assumed that the set $T$, satisfy the regularity conditions of no free lunch, is closed and convex, and has free disposability of inputs and outputs. Free disposability of inputs and outputs implies that if $(x, y) \in T$ and if $\left(x^{\prime}, y^{\prime}\right) \leq(x, y)$ then $\in T$.

For given a direction vector $g=\left(g_{x}, g_{y}\right)$ we model hospital's efficiency using the directional distance function. This function is defined as

$$
\vec{D}_{T}\left(x, y ;-g_{x}, g_{y}\right)=\max _{\beta}\left\{\beta \epsilon R:\left(x-\beta g_{x}, y+\beta g_{y}\right) \epsilon T\right\}
$$

The directional distance function (2) expands outputs in the direction $\mathrm{g}_{\mathrm{y}}$ and contracts inputs in the direction $g_{x}$ to te frontier $T$. That is, the solution oh $(2), \vec{D}_{T}\left(x, y ;-g_{x}, g_{y}\right)=\beta^{*}$, takes the observed input-output bundle, (x. y), to the boundary of $T$ at $\vec{D}_{T}\left(x-\beta^{*} g_{x}, y+\beta^{*} g_{y}\right)$. Clearly, the directional distance function measures technical inefficiency: a hospital is efficient if, and only if, it is on the frontier of $T$. i.e. $\beta^{*}=0$. If $\beta^{*}>0$, the hospital is inefficient.

Following Barros et al. (5) and Williams et al. (10), it is assumed that for the periods $\mathrm{t}$ and $\mathrm{t}$ +1 , each hospital (production unit) is represented by the production vectors $\left(x_{t}, y_{t}\right)$ and $\left(x_{t+l}\right.$, $y_{t+1}$ ), respectively. From (2) is clear, that either the technology of the period $\mathrm{t}$ or $\mathrm{t}+1$, can be used as reference technology to evaluate productivity change. In this case, the LPI proposed by Chambers et al. (8) and Chambers and Pope (52), can be used to measure the productivity change, The LPI is defined as follows:

$$
\begin{gathered}
L\left(x^{t}, x^{t+1}, y^{t}, y^{t+1}\right)=\left[\vec{D}_{T}^{t}\left(S^{t} ; g\right)-\vec{D}_{T}^{t+1}\left(S^{t+1} ; g\right)\right]+\frac{1}{2}\left[\left(\vec{D}_{T}^{t+1}\left(S^{t+1} ; g\right)-\vec{D}_{T}^{t}\left(S^{t+1} ; g\right)\right)+\left(\vec{D}_{T}^{t+1}\left(S^{t} ; g\right)-\right.\right. \\
\left.\left.\vec{D}_{T}^{t}\left(S^{t} ; g\right)\right)\right]
\end{gathered}
$$

Where $S^{t}=\left(x^{t}, y^{t}\right)$ and $S^{t+1}=\left(x^{t+1}, y^{t+1}\right)$ are the combinations of inputs and outputs for the periods $t$ and $t+1$ respectively, and inli13 represents the reference vector. The first term in square brackets measures the efficiency change between periods $t$ and $t+1$, while the arithmetic mean of the difference-based LPI in based year $t$ and $t+1$ of the second term in square brackets witch has been taken to avoid an arbitrary choise between based years, represents the technological change betwwn the two time periods. Positive (negative) values indicate productivity growth (decline).

Following Färe et al. (23), from all inputs and outputs of the $k=1, \ldots, K$ hospitals, we construct the reference technology for each of the $t=1, \ldots, T$ periods as follows: 


$$
T^{t}=\left\{\left(y_{k}^{t}, x_{k}^{t}\right): y_{m}^{t} \leq \sum z_{k}^{t} y_{k m}^{t}, x_{n}^{t} \geq \sum z_{k}^{t} x_{k n}^{t}, \quad z^{t} \in R_{+}^{k}\right\}
$$

where $\mathrm{z}_{k}$ are intensity variables that allow for the generation of convex combinations from the inputs and outputs of all hospitals. The constraints $y_{m}^{t} \leq \sum z_{k}^{t} y_{k m}^{t}$ and $x_{n}^{t} \geq \sum z_{k}^{t} x_{k n}^{t}$ model free disposition of inputs and outputs and $z^{t} \in R_{+}^{k}$ imposes constant returns of scale.From equation (4), the directional distance functions $\vec{D}_{T}^{t}(\cdot)$ and $\vec{D}_{T}^{t+1}(\cdot)$ are calculated by solving the following linear programs:

$$
\begin{gathered}
\vec{D}_{T}^{t}\left(S^{t} ; g^{t}\right)=\max _{\mathrm{z}, \beta} \beta^{t} \\
\text { s.a. } \sum_{k} z_{k}^{t} y_{k m}^{t} \geq y_{k^{\prime} m}^{t}+\beta y_{k \prime m}^{t}, \quad m=1, \ldots, M \\
\sum_{k} z_{k}^{t} x_{k n}^{t} \leq x_{k \prime m}^{t}-\beta x_{k \prime n}^{t}, \quad n=1, \ldots, N \\
z_{k}^{t} \geq 0, k=1, \ldots, K
\end{gathered}
$$

And,

$$
\begin{gathered}
\vec{D}_{T}^{t+1}\left(S^{t+1} ; g^{t+1}\right)=\max _{\mathrm{z}, \beta} \beta^{t+1} \\
\text { s.a. } \sum_{k} z_{k}^{t+1} y_{k m}^{t+1} \geq y_{k^{\prime} m}^{t+1}+\beta y_{k^{\prime} m}^{t+1}, \quad m=1, \ldots, M \\
\sum_{k} z_{k}^{t+1} x_{k n}^{t+1} \leq x_{k^{\prime} n}^{t+1}-\beta x_{k^{\prime} n}^{t+1}, \quad n=1, \ldots, N \\
z_{k}^{t+1} \geq 0, k=1, \ldots, K
\end{gathered}
$$

The combined distance functions are calculated by solving the linear programs

$$
\begin{gathered}
\vec{D}_{T}^{t+1}\left(S^{t} ; g^{t}\right)=\max _{\mathrm{z}, \beta} \beta \\
\text { s.a. } \sum_{k} z_{k} y_{k m}^{t+1} \geq y_{k \prime m}^{t}+\beta y_{k^{\prime} m}^{t}, \quad m=1, \ldots, M \\
\sum_{k} z_{k} x_{k n}^{t+1} \leq x_{k \prime n}^{t}-\beta x_{k \prime n}^{t}, \quad n=1, \ldots, N \\
z_{k} \geq 0, k=1, \ldots, K
\end{gathered}
$$


And,

$$
\begin{gathered}
\vec{D}_{T}^{t}\left(S^{t+1} ; g^{t+1}\right)=\max _{\mathrm{z}, \beta} \beta \\
\text { s.a. } \sum_{k} z_{k} y_{k m}^{t} \geq y_{k \prime m}^{t+1}+\beta y_{k \prime m}^{t+1}, \quad m=1, \ldots, M \\
\sum_{k} z_{k} x_{k n}^{t} \leq x_{k \prime n}^{t+1}-\beta x_{k \prime n}^{t+1}, \quad n=1, \ldots, N \\
z_{k} \geq 0, k=1, \ldots, K
\end{gathered}
$$

According to Fukuyama and Weber (53), the LPI can be added to measure the total level of productivity of the industry from the levels reached by each productive unit. This, with the aim of estimating the contribution of each company or groups of companies in the overall performance. As the authors point out, this is possible when productivity is evaluated in terms of a common reference vector for each firm.

Thus, in the present study, this methodology was used to determine the regional contribution on the productive performance registered in the hospital sample used. $\mathrm{T} \overline{x_{n}}, \overline{y_{m}}$ lis, in the required directional distance fun $\frac{\dot{\bar{x}}}{x_{n}}$ ns fo $\frac{-4}{y_{m}}$ e calculation of the LPI, $g=(\quad)$ was used as the reference vector, where and correspond to mean values of the variables selected for all hospitals. Therefore, for the calculation of the indicatir, the observed values of the sekected variables were considered together with their respective mean as reference vector.

According to the above, and as applied by Mussard and Peypoch (54), the aggregate indicator was broken down into its traditional attributes: efficiency change (convergence towards better practices and business technologies) and technological change (investment in technology and the innovation that produces a displacement of the production frontier), to determine the contribution of each region to these components.

The data comes from the Public Hospitals Management System of the Ministry of Social Protection. The database contains 1.006 hospitals for the 2004-2015 period. We omitted 746 hospitals in order to obtain a representative sample with hospitals sharing a similar nature and technology. For this, hospitals with at least one of these conditions were dropped: (i) have signed a liability restructuring agreement; (ii) have registered outliers, voids or zeros values on inputs or outputs; (iii) have been liquidated or merged; and (iv) have provided highly specialized services. As a result, the sample compiled was limited to 260 public hospitals for the 2004-2015 period, which resulted in 3.120 field observations within a balanced panel $^{8}$.

In the variables selection process, the following aspects were taken into account: i) the variables suggested in literature review; (ii) the existence of a relationship between inputs and outputs; iii) the relevance of the selected variables within the study goals; and iv) the availability of 
information. Under these criteria, and assuming that hospitals produce under the use of inputs, these were the variables used in the study:

Outputs: i) number of elective consultations; (ii) number of urgent consultations; (iii) number of deliveries; iv) number of discharges, that is, patients who, after being hospitalized, left the hospital; and v) days of stay, that is, days that each of the discharged patients were housed. Inputs: i) number of people in the care area; ii) number of people in the administrative area; iii) committed expenditure in millions of pesos; and iv) number of hospital beds.

Table 3 shows, by region, the descriptive statistics ${ }^{9}$. In general, hospitals in the Central, Pacific, Caribbean and Bogota regions concentrated a large part of the hospital inputs and outputs. However, the average statistics by hospital indicate that each hospital in Bogota and AmazoniaOrinoquia requires a greater amount of inputs, compared to the other regions.

Table 3 Descriptive statistics, 2004-2015

\begin{tabular}{|c|c|c|c|c|c|c|c|}
\hline $\begin{array}{l}\text { Variables / } \\
\text { Region }\end{array}$ & $\begin{array}{c}\text { Amazonia- } \\
\text { Orinoquia }\end{array}$ & $\begin{array}{c}\text { Bogotá } \\
\text { D. C. }\end{array}$ & Caribbean & Central & Eastern & Pacific & National \\
\hline \multicolumn{8}{|l|}{ Outputs } \\
\hline \multirow{3}{*}{$\begin{array}{l}\text { Elective } \\
\text { consultations }\end{array}$} & 27.016 & 99.710 & 25.781 & 21.408 & 26.029 & 41.809 & 29.701 \\
\hline & [3.859] & [11.079] & [645] & [200] & {$[554]$} & [836] & [114] \\
\hline & (10.963) & $(55.628)$ & $(15.066)$ & $(21.721)$ & (24.996) & $(58.207)$ & $(36.510)$ \\
\hline \multirow{3}{*}{$\begin{array}{l}\text { Urgent } \\
\text { consultations }\end{array}$} & 10.472 & 35.265 & 10.311 & 7.688 & 9.448 & 18.435 & 11.506 \\
\hline & [1.496] & [3.918] & [258] & [72] & [201] & [369] & [44] \\
\hline & (8.224) & (17.137) & (7.841) & (13.861) & $(12.707)$ & $(24.088)$ & $(16.635)$ \\
\hline \multirow{3}{*}{ Deliveries } & 446 & 1.348 & 252 & 184 & 235 & 327 & 279 \\
\hline & [64] & {$[150]$} & [6] & [2] & [5] & [7] & [1] \\
\hline & (508) & $(1.646)$ & (350) & (390) & (474) & $(621)$ & (584) \\
\hline \multirow{3}{*}{ Discharges } & 2.097 & 7.408 & 788 & 872 & 1.003 & 1.413 & 1.246 \\
\hline & {$[300]$} & [823] & [20] & [8] & {$[21]$} & [28] & [5] \\
\hline & $(2.723)$ & (7.164) & (1.129) & $(1.950)$ & (1.838) & $(2.151)$ & $(2.580)$ \\
\hline \multirow{3}{*}{ Days of stay } & 6.149 & 22.464 & 1.886 & 2.325 & 2.742 & 3.665 & 3.390 \\
\hline & [878] & {$[2.496]$} & [47] & {$[22]$} & {$[58]$} & [73] & [13] \\
\hline & $(8.383)$ & $(24.198)$ & (3.853) & (6.029) & $(5.099)$ & (6.314) & $(8.078)$ \\
\hline
\end{tabular}

Note: mean; [mean per hospital]; (standard deviation).

Source: author calculations based on data from MSP. 
Table 3 Descriptive statistics, 2004-2015 (Cont.)

\begin{tabular}{|c|c|c|c|c|c|c|c|}
\hline $\begin{array}{l}\text { Variables / } \\
\text { Region }\end{array}$ & $\begin{array}{l}\text { Amazonia- } \\
\text { Orinoquia }\end{array}$ & $\begin{array}{c}\text { Bogotá } \\
\text { D. C. }\end{array}$ & Caribbean & Central & Eastern & Pacific & National \\
\hline \multicolumn{8}{|l|}{ Inputs } \\
\hline \multirow{3}{*}{$\begin{array}{l}\text { Healthcare } \\
\text { personal }\end{array}$} & 40 & 145 & 26 & 25 & 34 & 37 & 33 \\
\hline & {$[5,7]$} & {$[16,1]$} & {$[0,7]$} & {$[0,2]$} & {$[0,7]$} & {$[0,7]$} & {$[0,1]$} \\
\hline & (34) & (81) & (15) & (29) & (34) & (43) & (41) \\
\hline \multirow{3}{*}{$\begin{array}{l}\text { Administrative } \\
\text { personal }\end{array}$} & 24 & 55 & 14 & 14 & 17 & 20 & 17 \\
\hline & {$[3,4]$} & {$[6,1]$} & {$[0,4]$} & {$[0,1]$} & {$[0,4]$} & {$[0,4]$} & {$[0,1]$} \\
\hline & (21) & (22) & (10) & (14) & (16) & (17) & (17) \\
\hline \multirow{3}{*}{$\begin{array}{l}\text { Committed } \\
\text { expenditure }\end{array}$} & 10.357 & 41.952 & 4.812 & 3.815 & 4.622 & 6.649 & 6.156 \\
\hline & [1.480] & {$[4.661]$} & [120] & [36] & [98] & [133] & [24] \\
\hline & (11.032) & (26.309) & (6.706) & $(5.640)$ & $(5.532)$ & $(8.372)$ & $(10.668)$ \\
\hline \multirow{3}{*}{ Hospital beds } & 33 & 80 & 14 & 12 & 21 & 20 & 19 \\
\hline & {$[4,7]$} & {$[8,9]$} & {$[0,4]$} & {$[0,1]$} & {$[0,4]$} & {$[0,4]$} & {$[0,1]$} \\
\hline & (24) & (71) & (15) & (17) & (19) & (20) & (25) \\
\hline $\begin{array}{l}\text { Number of } \\
\text { hospitals }\end{array}$ & 7 & 9 & 40 & 107 & 47 & 50 & 260 \\
\hline
\end{tabular}

Note: mean; [mean per hospital]; (standard deviation).

Source: author calculations based on data from MSP.

Maldonado and Tamayo (55) suggest that before performing the measurements of efficiency of public hospitals, these should be grouped with institutions that share similar characteristics, that is, making up comparable groups of hospitals. An initial criterion could be clustering by level of

complexity ${ }^{10}$. However, as Toro and Mutis (3) and Maldonado and Tamayo (55) point out, this criterion is not convenient since the level of complexity largely responds to an administrative characterization and not to a distinction on size, level, and the services provided. For instance, a first level hospital can provide second level services, due to the fact that hospitals are not restricted to providing services according to their classification by level of complexity. The other criterion is by cluster analysis, thus ensuring that each group is homogeneous in certain characteristics and the differences within them are minimal (56).

In this study, hospitals with common characteristics were grouped by cluster analysis. For this, following Toro and Mutis (3) we selected the following variables: i) the number of beds, to approximate the size of the hospital; (ii) committed expenditure, as a form of measurement of the technological level; and iii) the days of stay, as magnitude of the complexity of the services and of the patients seen. 
As suggested by Maldonado and Tamayo (55) and as applied by Toro and Mutis (3), the Ward method was used, as a linkage measure, for the conformation of each conglomerate ${ }^{11}$. The Ward method is a hierarchical procedure that maximizes homogeneity within each group. It uses the square sum of the deviations between each individual and the group average where it is integrated. The objective, at each stage of integration, is to minimize the increase in the square sum within each group (58).

For simplicity, hospitals were divided into two groups as indicated by the dendrogram obtained with the Ward link shown in figure 1. The cluster on the left is formed by 246 hospitals, whereas the group of the right includes 14 hospitals.

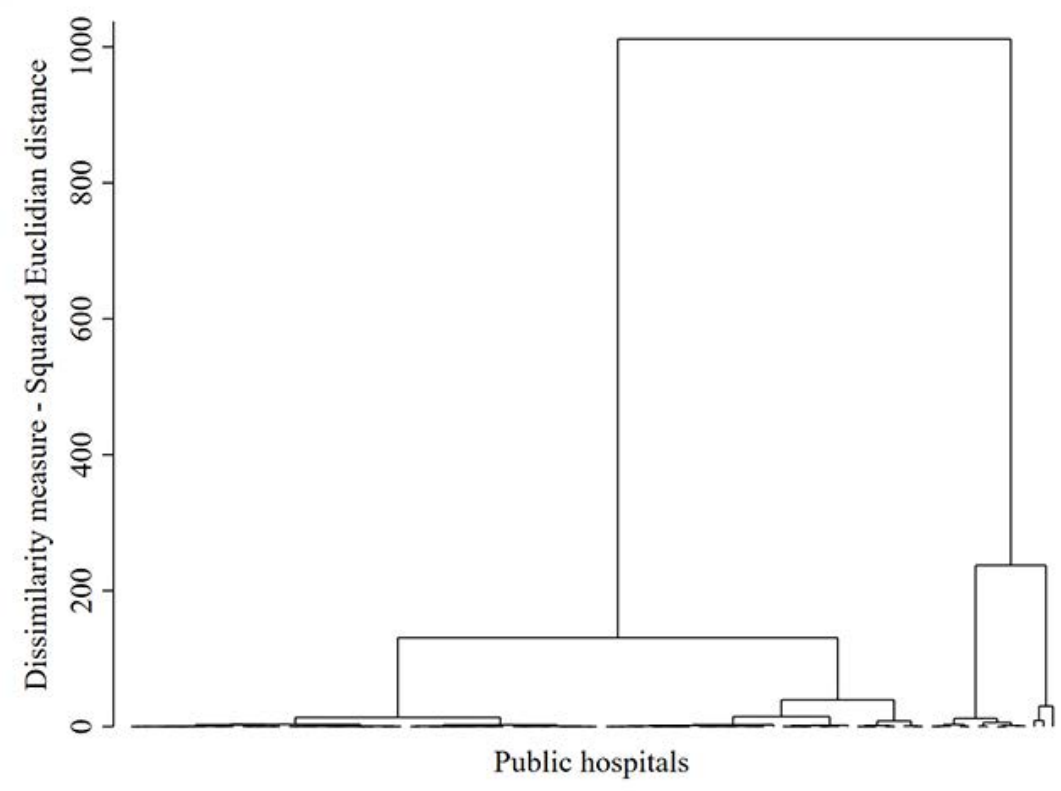

Figure 1 Dendrogram of public hospitals sample

Source: Own elaboration based on data from MSP.

\section{Results $^{12}$}

The analysis presented here seeks to evaluate the performance of hospitals' internal productive process, that is, the process with which each institution transforms inputs into outputs. External factors such as regulation, market structure and target population, among others, should be analyzed as explanatory factors of efficiency and productivity levels, obtained through the applied methodology, according to the literature. The reason behind the above is that by including these external conditions, each hospital would become a single observation with particular characteristics, which would detract from the methodological application, because it would be then evaluating hospitals that are not comparable to each other (55). Therefore, in this study, each hospital was approached according to its internal conditions, allowing its comparability by building relatively homogeneous groups in its production process. 
As shown in table 4, the negative value of the LPI in both groups of hospitals indicates a productivity decline during 2004-2015. The group of low complexity hospitals (Group 1) registered a decrease of $1.75 \%$. In turn, the most complex hospitals (Group 2) experienced a lower rate than Group 1, which was $0.56 \%$. Accordingly, institutions of low complexity are less efficient than those of greater complexity. The above is closely related to what Sarmiento et al. (62) and Toro and Mutis (3) found: their results indicate that efficiency increases with the level of complexity.

Table 4 Productivity change in Colombian public hospitals by group, 2004-2015

\begin{tabular}{|l|c|c|c|}
\hline \multicolumn{4}{|c|}{ Percentage (annual average) } \\
\hline \multirow{2}{*}{ Groups of hospitals } & $\begin{array}{c}\text { Luenberger } \\
\text { Indicator }\end{array}$ & $\begin{array}{c}\text { Efficiency } \\
\text { change }\end{array}$ & $\begin{array}{c}\text { Technological } \\
\text { change }\end{array}$ \\
\cline { 2 - 4 } & LI & EC & TC \\
\hline Group 1 & $-1,75$ & $-0,25$ & $-1,50$ \\
\hline Average & $-1,31$ & $-0,17$ & $-1,13$ \\
\hline Median & 1,98 & 1,57 & 1,58 \\
\hline Standard deviation & $-11,99$ & $-9,09$ & $-10,51$ \\
\hline Min & 3,90 & 5,70 & 4,49 \\
\hline Max & & & $-0,53$ \\
\hline Group 2 & $-0,56$ & $-0,03$ & $-0,20$ \\
\hline Average & $-0,07$ & 0,00 & 0,74 \\
\hline Median & 0,86 & 0,40 & $-1,71$ \\
\hline Standard deviation & $-2,05$ & $-1,03$ & 0,50 \\
\hline Min & 0,46 & 0,71 & \\
\hline Max & & & \\
\hline
\end{tabular}

Note: 37 cases of infeasibility were reported in the calculations. In view of this, Briec and Kerstens (63) recommend to report any infactibility case presented in the empirical application, considering that this fact is inevitable under certain specifications of the technology.

Source: Author calculations based on data from MSP. 
The decomposition of the LPI reveals that productivity decrease in both groups of hospitals was caused mainly by the fall in technological change (table 4). This suggests, as methodology and empirical evidence indicate, that the productivity decline of Colombian public hospitals was due to a lack of investment in technology and innovation. In other words, it was due to an insufficient accumulation of capital that limited the adoption of new technologies to generate greater and better results using the least amount of resources. Therefore, the incorporation of cost-effective techniques, equipment and drugs was hindered. As a result, scientific research and technological development were conditioned. MSP (59 p14) points out the absence of mechanisms for the evaluation and incorporation of technology in the country's health service providers to be a problem. Specifically, it indicates that "in many cases the introduction and incorporation of cost-effective techniques, equipment or drugs occurs late because of the absence of a technology assessment system in the country."

On the other hand, the decline in efficiency change is attributable to the lack of convergence towards best business practices. An example of a better business practice is when boards of directors and managers of a hospital, which are responsible for their management, make it possible for the institution to develop and guarantee service with efficiency and quality, through a better use of technical, human, material and financial resources. MSP (59 p15) warns of weaknesses in the management of the country's health service providers. In detail, it mentions that "management boards in general do not exercise the role of management and evaluation, and managers have left aside the issue of the quality of clinical management and human talent."

As in the national context, hospitals in all regions experienced on average a decrease in productivity. It was found that regions with major productive loss were: the eastern region, Amazonía-Orinoquía, and the Caribbean region. Between 2004 and 2015, the annual fall in hospital productivity in these areas averaged $2.06 \%, 1.70 \%$, and $1.68 \%$, respectively. While in Bogotá, the productivity decrease was smaller and averaged about $0.91 \%$ (table 5).

The decrease in technological change was the only source of productivity decline of Caribbean hospitals (table 5). This fact counteracted the progress achieved in efficiency change $(0.24 \%)$. The reason behind this is related to the scarce of technological investment and innovation within hospitals in this region, such as the limited adoption of new and better health technologies that boost the skills and knowledge of technical personnel. 
Table 5 Productivity change in Colombian public hospitals by region, 2004-2015

\begin{tabular}{|l|c|c|c|}
\hline \multirow{2}{*}{ Region } & $\begin{array}{c}\text { Luenberger } \\
\text { Indicator }\end{array}$ & $\begin{array}{c}\text { Efficiency } \\
\text { change }\end{array}$ & $\begin{array}{c}\text { Technological } \\
\text { change }\end{array}$ \\
\cline { 2 - 4 } & LI & EC & TC \\
\hline Amazonia-Orinoquia & $-1,70$ & $-0,10$ & $-1,59$ \\
\hline Bogotá D.C. & $-0,91$ & $-0,92$ & 0,01 \\
\hline Caribbean & $-1,68$ & 0,24 & $-1,92$ \\
\hline Central & $-1,63$ & $-0,50$ & $-1,12$ \\
\hline Eastern & $-2,06$ & $-0,06$ & $-2,00$ \\
\hline Pacific & $-1,62$ & $-0,14$ & $-1,48$ \\
\hline
\end{tabular}

Source: Author calculations based on data from MSP.

The decline in efficiency change largely explains the fall in productivity of Bogotá hospitals (table 5). This shows that the best practices in the management, care and administration of hospitals are not being applied. That is, they are not adequately implementing the processes of planning, acquiring, managing, using, optimizing and controlling the resources necessary to ensure an efficient health service.

In relation to the contribution of each component and region to the negative balance of hospital productivity, the table 6 shows that technological change was the mainly source of the fall. On the other hand, the regions that mostly contributed to the decline were the Central and Eastern ones, with contributions of $39.7 \%$ and $22.0 \%$. It should be mentioned that these zones were the main exponents of the technological decline. 
Table 6 Percentage contribution to the productivity fall by region and components, 2004-2015

\begin{tabular}{|c|c|c|c|}
\hline \multicolumn{4}{|c|}{ Percentage } \\
\hline \multirow{2}{*}{ Region } & $\begin{array}{l}\text { Luenberger } \\
\text { Indicator }\end{array}$ & $\begin{array}{l}\text { Efficiency } \\
\text { change }\end{array}$ & $\begin{array}{l}\text { Technological } \\
\text { change }\end{array}$ \\
\hline & LI & EC & TC \\
\hline Amazonía-Orinoquía & 2,7 & 0,2 & 2,5 \\
\hline Bogotá D.C. & 1,9 & 1,9 & 0,0 \\
\hline Caribbean & 15,3 & $-2,2$ & 17,5 \\
\hline Central & 39,7 & 12,2 & 27,4 \\
\hline Eastern & 22,0 & 0,6 & 21,4 \\
\hline Pacific & 18,5 & 1,6 & 16,9 \\
\hline Total & 100,0 & 14,3 & 85,7 \\
\hline
\end{tabular}

Source: Author calculations based on data from MSP.

The different combinations of changes in efficiency change and technological change experienced by hospitals are illustrated in figure 2. The percentage of institutions showing improvements in both components was minimal. In fact, only one out of 87 hospitals implemented the best business practices associated with optimum use of resources, joined with the acquisition of new technologies for greater dynamics in innovation.

Only $4.6 \%$ of the hospitals recorded an advance in technological change along with a decrease in efficiency change (figure 2). As mentioned by NG (35), this is attributable to the adoption of high technology treatments and therapies with costly procedures, among others, that allow to expand the production frontier. However, a non-optimal use of these inputs ends up deteriorating the efficiency change. This fact was more noticeable in Amazonía-Orinoquía and Bogotá, since $14.3 \%$ and $11.1 \%$ of the hospitals belonging to these zones showed the behavior in mention. 


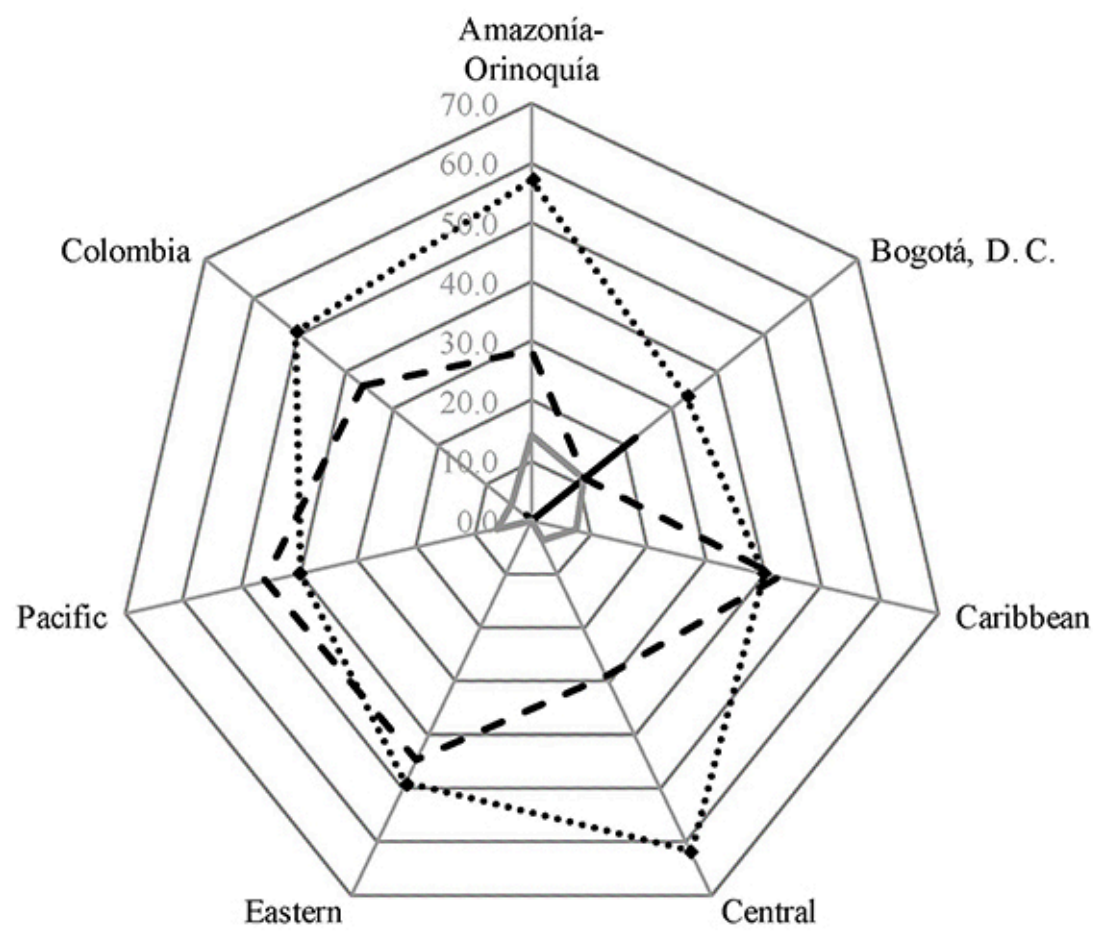

- Improved technical efficiency and technological change Deteriorated technical efficiency and improved technological change

- Improved technical efficiency and deteriorated technical change

$\cdots \leftrightarrow$.. Deteriorated technical efficiency and technological change

Figure 2 Combination of efficiency change and technological change

Source: Own elaboration based on data from MSP. 
One of every three hospitals experienced a progress in efficiency change along with a decline in technological change (figure 2). This is explained by the fact that, despite the implementation of best business practices and adequate use of resources, it did not generate enough capital to incorporate new technologies that would allow them to expand the production frontier. This behavior was evidenced in a large number of hospitals in the Caribbean, Eastern and Pacific regions.

The pattern most common in hospitals was going through a decline in efficiency change and technological change simultaneously. In fact, the half of the hospitals experienced this issue. In other words, one out of two Colombian hospitals lagged behind the adoption of best practices in business management, and this, coupled with a poor implementation of new technologies. This behavior, which took place in $61.7 \%$ of Central hospitals (as the most notable case), is the least desired by hospitals that hope to be efficient and productive.

\section{Discussion and conclusion}

The analysis of the efficiency and productivity of a sample of 260 Colombian public hospitals over the 2004-2015 period shows that on average hospitals experienced a deterioration of productivity over the eleven years. Thus, the efficiency and productivity that was sought to be achieved through the implementation of subsidies to demand in a market of regulated competition was insufficient. This fact is worth attention, and should become a policy priority within government efforts to improve efficiency and productivity in health service providers.

When evaluating efficiency and productivity by homogeneous groups of hospitals, it was found that less complex institutions are less efficient than those with more complexity. This allows deducing that not all institutions among the system present the same failings. Consequently, further analysis is needed to identify the sources of inefficiency and their difference between groups. From the above it is possible to infer that less complexity hospitals should adopt the managerial practicing and technology from the more complexity hospitals that could improve their efficiency, without fooled into the claim that the healthcare system must converge to the more complexity hospitals, due to their advantages in efficiency.

The fact that the decline in productivity has been caused mainly by the lag in technological change is one aspect that needs to be approached with caution. The reason behind the above is that technological change can be driven by greater investment in hospitals in conjunction with the adoption of new technologies. However, inadequate management of resources could lead to a detriment of efficiency change and, therefore, deepen the productivity fall.

The hospitals' performance of all regions showed a productivity decrease on average during the period. It was more pronounced in the Eastern region. Precisely, this area, along with the Central region accounted for about three-fifths of the overall negative productivity balance. Considering the importance of these regions in the national context in achieving health goals, 
special emphasis should be placed on assessing the factors that caused the productive detriment of their hospitals, as well as their impact on the quality of the services provided.

The fall in productivity observed in this sample of hospitals suggests the need for a comprehensive evaluation of the public hospital system as a whole. So, if the overall system is also found to have lost productivity, the policies proposed by the Government should be rethought to correct inefficiencies during the period analyzed. Therefore, without dissociating from the commitment to guarantee the quality and accessibility of services to users, governmental measures should be directed mainly at the following aspects:

1. Encouraging managers to modernize their administrative and organizational factors, based on the adoption of business models that guarantee the efficiency and quality of service.

2. Promoting the development of technology and research in health, through greater investments that make it possible to take advantage of and develop human talent within each organization.

3. Fostering complementary and non-competitive relationships among hospitals, in order to generate a continuous benefit that allows their sustainability.

The information available on hospital production only measures processes, not results. More clearly, only the type of care given to patients is evaluated, and not the result that this care had on their health. In this way, important aspects such as the quality of the service and the heterogeneity of the users are not considered. Thus, it is suggested to improve the information that measures the hospital output, so that the efficiency of a hospital is not only evaluated based on the use of its resources, but also according to the quality of service provided to the different types of patients.

\section{References}

1. Artaza O, Méndez CA, Holder R, Suárez JM. Redes integradas de servicios de salud: el desafío de los hospitales. Santiago, Chile: Biblioteca de la Oficina de OPS/OMS; 2011. http://www1.paho.org/chi /images/PDFs/redes_integrales_de_servicios.pdf?ua=1.

2. Uribe M. La dinámica de los actores en la implementación de la reforma del sistema de salud en Colombia: exclusiones y resistencias (1995-2003). Rev Gerenc Polit Salud. 2009;8(17): 44-68. https://revistas. javeriana.edu.co/index.php/gerepolsal/article/view/2656

3. Toro E, Mutis G. Medición de la eficiencia de las instituciones prestadoras de servicios de salud públicas mediante técnicas multivariadas y análisis envolvente de datos. Bogotá: Universidad de los Andes; 2006. https://repositorio.uniandes.edu.co/handle/1992/9379? locale-attribute=en 
4. Pinzón M. Medición de eficiencia técnica relativa en hospitales públicos de baja complejidad mediante la metodología Data Envelopment Analysis (DEA). Archivos de Economía, Bogotá: DNP; 2003. ht tps://colaboracion.dnp.gov.co/CDT/Estudios\%20Econmicos/245.pdf

5. Barros C, Menezes A, Peypoch N, Solonandrasana B, Vieira J. An analysis of hospital efficiency and productivity growth using the Luenberger indicator. Health Care Manag Sci. 2008 Jan;11(4): 373-381. https://doi.org/10.1007/s10729-007-9043-6

6. Worthington A. Frontier efficiency measurement in healthcare: a review of empirical techniques and selected applications. Med Care Res Rev. 2004;61(2): 1-36. https://doi.org/10.1177/107755870426 3796

7. Charnes A, Cooper W, Lewin A, Seiford L. Data envelopment analysis: theory, methodology and application. Boston: Kluwer; 1994.

8. Chambers RG, Chung Y, Färe R. Benefit and distance functions. J Econ Theory. 1996;70(2): 407-419. https://doi.org/10.1006/jeth.1996.0096

9. Shephard RW. Theory of cost and production function. New Jersey: Princeton University Press; 1970.

10. Williams J, Peypoch N, Barros C. The Luenberger indicator and productivity growth: a note on the European savings banks sector. Appl Econ. 2011;43(6): 747-755. https://doi.org/10.1080/00036840 802599859

11. Peñaloza MC. Evaluación de la Eficiencia en instituciones hospitalarias públicas y privadas con Data Envelopment Analysis (DEA). Archivos de Economía, Departamento Nacional de Planeación. Bogotá: DNP; 2003. https://colaboracion.dnp.gov.co/CDT/Estudios\%20Econmicos/244.pdf

12. Reina M, Yanovich D. Proyecto Agenda Colombia. Cuadernos de Fedesarrollo, vol. I: Salud, educación y desempleo diagnóstico y recomendaciones. Bogotá: Tercer Mundo Editores; 1998.

13. Tinbergen J. Zur Theorie Der Langfristigen Wirtschaftsentwicklung. Weltwirtschaftliches Archiv. 1942;55: 511-549. https://www.jstor.org/stable/140019409

14. Kittelsen SAC, Winsnes BA, Anthum KS, Goude F, Hope Ø, Häkkinen U, et al. Decomposing the productivity differences between hospitals in the Nordic countries. J Prod Anal. 2015;43: 281-293. https://www.frisch.uio.no/publikasjoner/pdf/1201.pdf

15. Nghiem S, Coelli T, Barber S. Sources of productivity growth in health services: a case study of Queensland public hospitals. Economic Analysis and Policy. 2011;41(1): 37-48. https://doi.org/10. 1016/S0313-5926(11)50003-7

16. Linna M. Measuring hospital cost efficiency with panel data models. Health Econ. 1998;7(5): 415-427. https://doi.org/10.1002/SICI1099-10501998087:5415::AID-HEC3573.0.CO2-9

17. Gabbitas O, Jeffs C. Assessing productivity in the delivery of public hospital services in Australia: some experimental estimates. Paper presented at: The 30th Australian Health Economics Conference; 2008 Oct 2-3; Adelaide, Australia.

18. Granderson G, Tauchen H. The impacts of membership in multi-hospital systems on cost, productivity growth and technical change. Appl Econ. 2016;48(18): 1633-1646. https://doi.org/10.1080/000368 46.2015.1105922 
19. Chowdhury H, Zelenyuk V, Laporte A, Wodchis WP. Analysis of productivity, efficiency and technological changes in hospital services in Ontario: How does case-mix matter? Int J Prod Econ. 2014;150: 74-82. https://doi.org/10.1016/j.ijpe.2013.12.003

20. Wu CH, Chang CC, Chen PC, Kuo KN. Efficiency and productivity change in Taiwan's hospitals: a non-radial quality-adjusted measurement. CEJOR. 2013;21: 431-453. http://hdl.handle.net/10.1007 /s10100-012-0238-7

21. Burgess JF, Wilson PW. Decomposing hospital productivity changes, 1985-1988: A nonparametric Malmquist approach. J Prod Anal. 1995;6: 343-363. https://doi.org/10.1007/BF01073525

22. McCallion G, Glass C, Jackson R, Kerr C, McKillop D. Investigating productivity change and hospital size: a nonparametric frontier approach. Appl Econ. 2000;32(2): 161-174. https://doi.org/10.1080/0 00368400322859

23. Färe R, Grosskopf S, Lindgren B, Roos P. Productivity developments in Swedish hospitals: a Malmquist output index approach. In: Charnes A et al. (eds). Data Envelopment Analysis: Theory, Methodology, and Applications. Boston: Kluwer; 1994. p.253-272.

24. Kirigia J, Emrouznejad A, Cassoma B, Asbu E, Barry S. A performance assessment method for hospitals: the case of municipal hospitals in Angola. J Med Syst. 2008;32: 509-519. https://doi.org/10.1007/s 10916-008-9157-5

25. Tlotlego N, Nonvignon J, Sambo LG, Asbu EZ, Kirigia JM. Assessment of productivity of hospitals in Botswana: a DEA application. Int Arch Med. 2010;3: 14. https://doi.org/10.1186/1755-7682-3-27

26. Gok S, Sezen B. Capacity inefficiencies of teaching and non-teaching hospitals. Serv Ind J. 2012;32(14): 2307-2328. https://doi.org/10.1080/02642069.2011.582495

27. De Castro MS, Ozcan YA, Da Silva ACM, Estellita MP, Fiszman R. Financing reform and productivity change in Brazilian teaching hospitals: Malmquist approach. CEJOR. 2010;18: 141-152. https://doi .org/10.1007/s10100-009-0097-z

28. Wei CK. Measuring efficiency and productivity change in Taiwan hospitals: a nonparametric frontier approach. J Am Acad Business. 2006;10(1): 317-323. https://doi.org/10.1177/097206341101300201

29. Dimas G, Goula A, Soulis S. Productive performance and its components in Greek public hospitals. Oper Res Int J. 2012;12: 15-27. https://doi.org/10.1007/s12351-010-0082-2.

30. Karagiannis R, Velentzas K. Productivity and quality changes in Greek public hospitals. Oper Res Int J. 2012;12: 69-81. https://doi.org/10.1007/s12351-010-0080-4

31. Huerta T, Ford E, Ford W, Thompson M. Realizing the value proposition: A longitudinal assessment of hospitals' total factor productivity. J Health Eng. 2011;2(3): 285-302. https://doi.org/10.1260/20 40-2295.2.3.285.

32. Li H, Dong S, Liu T. Relative efficiency and productivity: a preliminary exploration of public hospitals in Beijing, China. BMC Health Serv Res. 2014;14: 158. https://doi.org/10.1186/1472-6963-14-158. 
33. Mogha S, Yadav S, Singh S. Technical efficiency and productivity growth in public sector hospitals of Uttarakhand (India). Int J Syst Assur Eng Manag. 2015;6: 390-406. https://www.infona.pl/resource /bwmeta1.element.springer-doi-10_1007-S13198-014-0270-1

34. Sulku SN. The health sector reforms and the efficiency of public hospitals in Turkey: provincial markets. Eur J Public Health. 2011;22(5): 634-638. https://doi.org/10.1093/eurpub/ckr163

35. NG YC. The productivity efficiency of Chinese hospitals. China Econ Rev. 2011;22(3): 428-439. http s://doi.org/10.1016/j.chieco.2011.06.001

36. Ferrier GD, Valdmanis VG. Do mergers improve hospital productivity? J Oper Res Soc. 2004;50(10): 1071-1080. https://doi.org/10.1186/2191-1991-3-3

37. Roh CY, Moon MJ, Park C. Economic performance of U.S. non-profit hospitals using the Malmquist productivity change index. Journal of Management and Marketing Research. 2011. http://www.aab ri.com/manuscripts/11869.pdf

38. Roh CY, Moon MJ, Park C. Measuring economic performance of Colorado community hospitals using the Malmquist productivity change index. Int Rev Publ Adm. 2011;16(1): 91-111. https://doi.org/1 $0.1080 / 12264431.2011 .10805187$

39. Chu CL, Chiang TL, Chang RE. Hospital competition and inpatient services efficiency in Taiwan: a longitudinal study. Health Econ. 2011;20(1): 1268-1280. https://doi.org/10.1002/hec.1676.

40. Chen SN. Productivity changes in Taiwanese hospitals and the national health insurance. Serv Ind J. 2006;26(4): 459-477. https://doi.org/10.1080/02642060600622355

41. Chang SJ, Hsiao HC, Huang LH, Chang H. Taiwan quality indicator project and hospital productivity growth. Int J Manag Sci. 2011;39(1):14-22. https://doi.org/10.1016/j.omega.2010.01.006

42. Arocena P, García-Prado A. Accounting for quality in the measurement of hospital performance: evidence from Costa Rica. Health Econ. 2007 Jul;16(7): 667-685. https://doi.org/10.1002/hec.1204

43. Pham TL. Efficiency and productivity of hospitals in Vietnam. J Health Organ Manag. 2011;25(2): 195-213. https://doi.org/10.1108/14777261111134428

44. Sommersguter-Reichmann M. The impact of the Austrian hospital financing reform on hospital productivity: empirical evidence on efficiency and technology changes using a non-parametric inputbased Malmquist approach. Health Care Manag Sci. 2000;3(4): 309-321. https://doi.org/10.1023/a: 1019022230731

45. Maniadakis N, Thanassoulis E. Assessing productivity changes in UK hospitals reflecting technology and input prices. Appl Econ. 2000;32(12): 1575-1589. https://doi.org/10.1080/000368400418970

46. Zere E, McIntyre D, Addison T. Technical efficiency and productivity of public sector hospitals in three South African provinces. S Afr J Econ. 2001;69(2): 336-358. https://doi.org/10.1111/j.1813-6982.2 001.tb00016.x

47. Sola M, Prior D. Measuring productivity and quality changes using data envelopment analysis: an application to Catalan hospitals. Financial Accountability \& Management. 2001;17(3): 219-245. ht tps://doi.org/10.1111/1468-0408.00129 
48. Gannon B. Total factor productivity growth of hospitals in Ireland: A nonparametric approach. Appl Econ Lett. 2008;15(2): 131-135. https://doi.org/10.1080/13504850600706115

49. Nabilou B, Yusefzadeh H, Rezapour A, Fard AF, Safi P, Asiabar A, Ahmadzadeh N. The productivity and its barriers in public hospitals: case study of Iran. Med J Islam Repub Iran. 2016;30(1): 36-43. http://mjiri.iums.ac.ir/article-1-3431-en

50. O'Meara G, Ruiz F, Acosta N, Arango F, Lara E, Peñaloza E, et al. Estrategias de producción y mercado para los servicios de salud. Cendex, Fundación Corona, Fundación Antonio Restrepo Barco, Colombia; 2001.

51. Cortés AE. La economía de la salud en el hospital. Rev Gerenc Polit Salud. 2010;9(19): 138-149. http ://www.scielo.org.co/pdf/rgps/v9n19/v9n19a10.pdf

52. Chambers R, Pope R. Aggregate productivity measures. Am J Agr Econ. 1996;75(5): 1360-1365. http s://ideas.repec.org/a/oup/ajagec/v78y1996i5p1360-1365.html

53. Fukuyama H, Weber WL. Efficiency and profitability in the Japanese banking industry. In: Färe R, Grosskopf S (eds.) Efficiency and Profitability: New Directions. Dordrecht: Kluwer; 2004. p.133-146.

54. Mussard S, Peypoch N. On multi-descomposition of the aggregate Luenberger productivity index. Appl Econ Lett. 2006;13(2): 113-116. https://doi.org/10.1080/13504850500378312

55. Maldonado N, Tamayo A. Estudio Integral de Eficiencia de los Hospitales Públicos. Archivos de Economía, Departamento Nacional de Planeación. Bogotá: DNP; 2007. https://colaboracion.dnp.go v.co/CDT/Desarrollo\%20Social/338_Eficiencia_tecnica_hospitales.pdf

56. Karlsson C. Handbook of research on cluster theory. United Kingdom: Edward Elgar; 2008. 336 p.

57. Kuiper FK, Fisher L. A Monte Carlo comparison of six clustering procedures. Biometrics. 1975;31(3): 777-783. https://doi.org/10.1186/1029-242X-2013-203

58. Everitt BS, Landau S, Leese M, Stahl D. Cluster analysis. 5th ed. United Kingdom: King's College London; 2011. 346 p.

59. Ministerio de la Protección Social. Política Nacional de Prestación de Servicios de Salud. Bogotá, Colombia: Ministerio de la Protección Social; 2005. 78 p. https://www.minsalud.gov.co/Min isterio/Documents/Politica \%20Nacional\%20de\%20Prestaci\%C3\%B3n\%20de\%20Servicios\%20de $\%$ 20Salud.pdf

60. Tono TM, Cueto E, Giuffrida A, Arango CH, López A. Hospitales públicos y reforma del servicio de salud. In: Glassman A, Escobar M, Giuffrida A, Giedion U (eds.) Salud al alcance de todos: una década de expansión del seguro médico en Colombia. Washington: Banco Interamericano de Desarrollo and The Brookings Institution; 2010. p.85-114.

61. Ministerio de Salud y Protección Social. Sistema de Salud en Colombia. In: Giovanella L, Feo O, Faria M, Tobar S, editors. Sistemas de salud en Suramérica: desafíos para la universalidad, la integralidad y la equidad. Rio de Janeiro: Instituto Suramericano de Gobierno en Salud; 2012. p.349-440. 
62. Sarmiento A, Castellanos W, Nieto AC, Alonso CE, Pérez CA. Análisis de eficiencia técnica de la red pública de prestadores de servicios dentro del Sistema General de Seguridad Social en Salud. In: Archivos de Economía, Departamento Nacional de Planeación. Bogotá: DNP; 2005. https://colabor acion.dnp.gov.co/CDT/Estudios\%20Econmicos/298.pdf

\section{Briec W, Kerstens K. The Luenberger productivity indicator: an economic specification leading to} infeasibilities. Econ Model. 2009;26(3): 597-600. https://doi.org/10.1016/j.econmod.2009.01.007

Notes

* Research paper.

1 Public hospitals became Social Enterprises of the State. These constitute a special category of public entity: decentralized, with legal personality, own property and administrative autonomy. (Article 1, Decree 1876 of 1994). 2The POS is the basic set of health care services contained in a list of medications, services, and procedures. 3It is important to emphasize that EPSs may have their own health service providers. 4The systems' financing comes mainly from national and subnational transfers and RS' resources.

2 The POS is the basic set of health care services contained in a list of medications, services, and procedures.

3 It is important to emphasize that EPSs may have their own health service providers.

$4 \quad$ The systems' financing comes mainly from national and subnational transfers and RS' resources.

5 Sales revenue resources differ from public to private hospitals mainly on compulsory insurances' minimal fee, which could affect efficiency comparisons between them. Contributions ins cash and in-kind resources refers to equipment, supplies, facilities and investment, among others, granted by National Government, regional authorities and other agents such as: universities in arrangement with the hospital for academic practicing and some specific taxes for hospitals' financing support.

6 The authors reviewed 37 articles that assess hospital productivity change over time. Thirty-two used DEA to estimate the production frontier, three applied DEA and stochastic frontier analysis (SFA) simultaneously (14-6), only one employed SFA (17), and the other one use an approximation to a divisia index (18). In order to determine productivity change, thirty-four articles applied Malmquist productivity index (MPI), one combined MPI with a non-parametric density estimation (19), and other with Luenberger productivity indicator (5); the remaining used other methods such as Tornqvist divisia index (18), Russell-Malmquist-Luenberger productivity index (20), and random and fixed effects model (17).

7 This is an advantage in the case of hospitals, since, as O'Meara et al. (50) state, if each of the hospital output is treated in isolation, the integrity and composition of the inputs is lost.

8 A balanced panel was used, despite the methodology not requiring it, in order to omit hospitals that may impair the analysis.

9 The conformation of each region is as such: Amazonia-Orinoquia covers Amazonas, Arauca, Casanare, Guainía, Guaviare, Putumayo, Vaupés, and Vichada. The Caribbean covers Atlántico, Bolívar, Cesar, Córdoba, La Guajira, Magdalena, San Andrés y Providencia, and Sucre. The Central covers Antioquia, Caldas, Caquetá, Huila, Quindío, Risaralda, and Tolima. The Eastern covers Boyacá, Cundinamarca, Meta, Norte de Santander, and Santander. Finally, the Pacific covers Cauca, Chocó, Nariño, and Valle del Cauca.

10 In Colombia, public hospitals are classified in three grades, according to the endowment and capacity they offer. At first level belong local hospitals that offers basic attention. At second level, regional hospitals with some specialized services and a laboratory. Third level, hospitals with highly specialized services.

11 Kuiper and Fisher (57) found that this method is the most accurate, compared to other methods (minimum distance, maximum distance, mean and centroid) for optimum conglomerate conformation.

12 It is important to note that the analysis of the results, as well as the conclusions derived therefrom, are framed within the interpretations that the methodology and the empirical evidence use. However, and in order to contextualize these interpretations for the Colombian case, these were complemented based on the document "National Policy of Provision of Health Services" (Politica Nacional de Prestación de Servicios de Salud) of the MSP (59). In addition, they were also supported by the studies of: Tono et al. (60), MSP (61), Artaza et al. (1) and O'Meara et al. (50). 